\title{
Society for the Prevention of Cruelty to Animals (Spolek pro ochranu zviřat)
}

Author: Jiřî Robert Pick

First Published: 1969

Translations: Hungarian (Állatvédö liga, 1986); German (Der Tierschutzverein, 2013); Polish (Towarzystwo opieki nad zwierzętami, 2015), English (Society for the Prevention of Cruelty to Animals, 2018).

About the Author: J. R. Pick (1925-1983) came from a Czech-Jewish family, his father was a chemistry engineer. In 1939, after the Nazi occupation, Pick had to interrupt his studies at high school. In 1943 he and his family were transported to the Theresienstadt Ghetto. His father was killed in 1944, Pick, his mother and his sister survived. Returning from the ghetto in 1945, Pick was treated for lung disease. In 1948 his mother and his sister emigrated to Argentina. Later his sister Zuzana Justman (born 1931) gained reputation as a documentary filmmaker and writer also with the topics of the Shoah. After World War II, J. R. Pick studied at the School of Political and Economic Sciences in Prague. In this time he began to write texts for theatre scenes and cabarets. In 1959 he founded the Paravan Theatre in Prague. He was its chief author and artistic director.

Due to the suppression of the Prague Spring, during the so-called normalisation in the 1970s, Pick was not allowed to publish again until 1980. At the beginning of 1980s two his plays were staged: A Dream about Distant Lakes and The Unlucky Man in the Yellow Cap. They are set in the Theresienstadt Ghetto and their black humour continues in tragicomic scenes of the novella Society for the Prevention of Cruelty to Animals (1969).

Further Important Publications: Sen o vzdálených jezerech (1981, premiered 1980, A Dream about Distant Lakes; play); Smolař ve žluté čepici (1982, premiered 1982, The Unlucky Man in the Yellow Cap; play); Pickanterie. Koláž ze života a díla J. R. Picka (Picquancy: A Collage from J. R. Pick’s Life and Work, 1995, ed. E. Světlík); Př́liš mnoho př́buzných (1996, To Many Relatives; novella).

\section{Content and Interpretation}

The story, divided in eleven chapters, takes place in the Theresienstadt Ghetto in the autumn of 1944. At that time, in September and October, the last big wave of transports from Theresienstadt to Auschwitz was going on. The story is narrated in the third person mainly from the point of view of the main character, the fourteen-year-old boy Tony (Toni in the Czech original). He is lying in a hospital with a mild form of tuberculosis. Tony is placed in a room with some older men. Sometimes his mother Líza visits 
him; he had lived with her in the ghetto for two years. He also often meets Líza's friends, young people about twenty.

Tony is bored in the hospital and gets excited with an idea to establish the Society for the Prevention of Cruelty to Animals in the ghetto. However, there are almost no animals here. It is forbidden for Jews to keep pets. Tony's friends think up the plan that they will take care of the dog of the Nazi SS-Sturmbannführer, a commander in the ghetto. They kidnap the dog and nevertheless, against Tony's expectations, they kill and eat it. They want to help Alba Feld who has gotten a summons to the transport to the East. Later another one of Tony's friends, Ledecký, brings him a mouse into the hospital. Ledecký announces that he and Jenda Schleim are also leaving with the transport. The ghetto is more and more depopulated, almost all of Tony's friends, as well as most of the patients receive summons to the transports. Ernie Jelinek decides not to enter the transport and to escape from the ghetto. Tony wants to flee with him but he is too late, because the nurse didn't let him out of the hospital. Ernie is shot by a German guard. Eventually the transport threatens Tony and his mother Líza. Tony pretends to spew blood and so they are both saved. The novella ends with Tony's first love experience with the nurse Lili.

The book's specific feature is just humour - it manifests itself in situations and in language. Tony is naive, he does not realise the seriousness of the circumstances. His interest in animal protection is in contrast to the harsh, often tragic existence of the Jews in the ghetto. Irrespective of it, many situations in Theresienstadt are absurd or grotesque.

Comic and curious characters are also inmates in the ghetto. For instance the German teenager and unwavering Nazi Horst Munther, a former member of Hitlerjugend. He was sent to the ghetto because it was found out his grandfather was a Jew. Or Mr Kohn who articulates antisemitic opinions.

Nevertheless, not only Tony is naive, but also many adult Jews in the ghetto. So professor Steinbach, a patient in the hospital, declares that Theresienstadt is just a transfer station to travel to the Promised Land. He is assured that everyone will soon reach Palestine. He plans to teach Czech literature at Tel Aviv University without being able to speak or understand Hebrew or Yiddish. This situation is on the border of black humour because Steinbach is transported within a few days to Auschwitz.

The atmosphere of the Theresienstadt Ghetto is presented in many slang expressions indicating life, customs and institutions in Theresienstadt. The author explains some of them in the footnotes.

\section{Main Topics and Problems}

J. R. Pick is one of the first authors to use the perspective of a child in Czech Holocaust literature. See Arnošt Lustig's $\rightarrow$ Diamonds of the Night, Josef Škvorecký's $\rightarrow$ The Menorah or Ota Pavel's $\rightarrow$ The Death of the Beautiful Deer; in the Polish literature see Henryk Grynberg's $\rightarrow$ The Jewish War and Wilhelm Dichter's $\rightarrow$ God's Horse; in the Slovak literature Vincent Šikula's $\rightarrow$ Lilies of Erika or Peter Krištúfek's $\rightarrow$ Emma and the 
Death's Head Hawkmoth. Children are generally considered to be naive, innocent, honest and unburdened by the value judgements of adults. On the other hand, child narrators are often incapable of understanding and putting things into a broader context. He or she distorts facts, focuses on detail instead of essential things. All this is visible in Society for the Prevention of Cruelty to Animals. Tony's thinking seems to be often too naive in view of his age of fourteen (Sladovníková, 2016, p. 807), because it is also known that children grew up prematurely in ghettos and camps.

From time to time, the author exchanges Tony's childish perspective for the perspective of an adult narrator.

Some of the topics in Society for the Prevention of Cruelty to Animals are erotica and sex. The historian Anna Hájková researched the sexual behaviour of Jewish inhabitants in the Theresienstadt Ghetto. She came to the conclusion that young prisoners in Theresienstadt perceived romantic erotic relationships and sex as a beautiful, relevant and legitimate way to spend time there (Hájková, 2013). Also some diaries from Theresienstadt testify to it (Hana Bořkovcová, Eva Rodenová or the unpublished diary of Willy Mahler, see Arnošt Goldflam's $\rightarrow$ Sweet Theresienstadt).

The walk to the Catholic church in the ghetto that ends with a "little party" can serve as an example. Tony is sent back to the hospital and so he learns about everything a few days later during Jenda Schleim's visit:

"Ledecký served as priest", he said, "and every ten minutes he paired off another two couples. Almost everyone there got a chance to be married to all the girls".

"But a priest can only do weddings, not divorces", Tony said.

Clearly he picked up some knowledge from the learned gentlemen in room 26.

"No one really took it that seriously", said Jenda. "Then, at the end, I took over from Ledecký, so he could -"

"So he could what", Tony asked.

"So he could get married too", Jenda said with some hesitation.

(p. 70)

The open presentation of erotic and sexual situations was in the Holocaust literature in the 1960s - unlike contemporary literary works in last decades - very rarely. Compared for instance with late novels of Arnošt Lustig, Society for the Prevention of Cruelty to Animals depicts this topic gently and only in hints.

J. R. Pick used his own experience from the Theresienstadt Ghetto. The story about Tony continues in the early 1950s in Prague in his novella Too Many Relatives (written 1971, edited 1996) where as a student Tony is confronted with the Stalinist antisemitism and is expelled from university. All of these works mix tragic, comic and erotic situations. In comparison with other literary works about the Theresienstadt Ghetto, Pick's works are unconventional, close only to Arnošt Goldflam.

\section{Cited Works}

Hájková, A. (2013). Sexual Barter in Times of Genocide. Negotiating the Sexual Economy of the Theresienstadt Ghetto. Chicago Journal, 38(3), pp. 503-533. Pick, J. R. (1996). 
Spolek pro ochranu zvířat. In: J. R. Pick, Toniho šance. Praha: Marsyas, pp. 5-125. Pick, J. R. (2018). Society for the Prevention of Cruelty to Animals. Praha: Karolinum. Sladovníková, Š. (2016). Dětský pohled na holokaust. In: J. Holý, ed., Cizí i blízcí. Židé, literatura, kultura v českých zemích ve 20. století. Praha: Akropolis, pp. 797-839.

\section{Further References}

Heřman, Z. (1995). Fenomén Pick. Tvar, 6(9), p. 12 and (10), p. 12. Justman, Z. (2018). Vzpomínka na mého bratra. In: J. R. Pick, Spolek pro ochranu zvířat. Praha: Karolinum, pp. 197-199. Sus, O. (1969). Maličtí, jež plyn losoval jako věc. Host do domu, 16(18), p. 40. Světlík, E. (ed.). (1995). Pickanterie: Koláž ze života a díla J. R. Picka. Praha: Marsyas. Tomáš, F. (2011). Humoristická - pokud je to možné - reprezentace holokaustu. In: J. Holý et al., Šoa v české literatuře a v kulturní paměti. Praha: Akropolis, pp. 255278. Topol, J. (2018). Smích v temnotách. In: J. R. Pick, Spolek pro ochranu zvírat. Praha: Karolinum, pp. 190-196.

JH 